\title{
FOTOGRAFIA E INTERDITO
}

\author{
Mauro Guilherme Pinheiro Koury
}

Este ensaio trabalha com a problemática do interdito e sua relação com o objeto fotográfico. Discute, ainda, as imagens traumáticas como representações culturais do sofrimento social, as diversas formas de apropriação para propósitos políticos ou morais, o uso social do sofrimento e a criação de um mercado pulsante para imagens e discursos sobre o tema na contemporaneidade.

A primeira hipótese de trabalho busca compreender como as diversas formas de apropriação da imagem fotográfica, com temáticas de interditos sociais ou que representam cenários liminares, parecem se fazer a partir da intencionalidade do ato em função da pessoa e, desse modo, aparecem para o observador comum como uma forma de apropriação não social do produto da ação. As imagens de interdito funcionam como um plano moral singular que tende a retirar do social qualquer vínculo que possa ter com a ação ou com o

Artigo recebido em março/2003

Aprovado em novembro/2003 fato de ser uma "coisa proibida", passando-o para o interior do indivíduo como uma subjetividade.

A segunda hipótese, conseqüência da primeira, analisa o objeto fotográfico a partir da idéia de experiência abstrata. Ao trabalhar em cenários de fronteira, no alcance dos códigos morais e na especificidade dos códigos de interdito e de poluição, esse objeto parece retratar situações de sofrimento na ambivalência entre abrangência e especificidade $e$ na ambigüidade das regras morais e das expressões poluidoras e interditas. Isso o torna um subproduto de uma ação legal ou legítima exercida institucionalmente ou, ainda, na esfera privada, uma ameaça concreta ou potencial dos medos gerais que conformam os indivíduos sociais.

\section{Fotografia e interdito}

As fotografias analisadas aqui revelam duas temáticas que interagem uma com a outra. Embora 
possam ser entendidas em separado, tornam-se mais expressivas e ganham sentido nos intercruzamentos que conduzem à leitura do plano social, para quem elas buscam revelar e de onde são produtos e objetos de discurso e também promotoras de falas competentes ou de projetos discursivos. Essas duas temáticas tratam da morte e dos interditos: ambas produtoras de discursos morais que servem de guia para um específico societário situar-se e situar seus membros em formas de conduta no tempo e no espaço, consolidando noções de passado e futuro por meio da presentificação da regra.

Interdito indica uma ação intentada com o fim de proteção e caracterizada por um preceito proibitório, como o impedimento do uso, a fruição de bens ou o obstáculo ao acesso a lugares ou a coisas considerados sagrados ou puros. ${ }^{1}$ Relacionase com noções de proibição e impedimento, e com a noção de poluição e contaminação. O uso de recursos interditos socialmente, assim, poderá acarretar prejuízos individuais e sociais para quem dele participa, ativa ou passivamente. Prejuízos que podem ir desde a perturbação mental ou social, até a constrangimentos pessoais ou coletivos entre partes em interação expostas ao recurso interdito.

Os prejuízos decorrentes da exposição possibilitam uma contaminação do sujeito exposto pelos elementos poluidores constantes da ação ou da coisa proibida. Uma coisa interdita, assim, quando tocada por mãos ou olhares pode provocar um ato poluente e criar uma área de contaminação que ocasiona perigos vários aos envolvidos diretos ou indiretos do ato de exposição.

As ações e as coisas interditas estão, portanto, sujeitas a todo um regramento pela disfuncionalidade que podem causar aos indivíduos ou a grupos societais, interagindo em tempo e espaço específicos. Os interditos podem ser considerados em suas formas de apropriação no plano social, por uma pessoa ou grupo de referência, e em suas formas simbólicas expressas no conteúdo imaginário, não necessariamente consciente daqueles que a manipulam, se expõem ou são expostos (Eliade, 1992).

A eficácia de um interdito é a sua aceitação social, por toda a coletividade ou por parte dela. Quanto mais simples o meio social, mais a noção do interdito perpassa todas as camadas e funciona na sociedade em geral. A pluralidade apresentada por um meio social mais complexo, diferentemente, permite a existência de fragmentações de vários níveis e graus no plano social, dissolvendo os interditos em um conjunto de regras passíveis de serem ou não absorvidas ou aceitas pelo todo.

Os interditos como padrões morais, em todo caso, são ressignificados cotidianamente pelos indivíduos, grupos e pela sociedade como um todo. Trata-se de uma espécie de imposição imaginária que toca em padrões arquetípicos de comportamento e de interação entre indivíduos ou grupos de um determinado meio social, ou, ainda, nas formas diversas de apropriação das ações de interditos entre os diversos grupos ou personagens envolvidos, passivos ou ativos, com o resultado da ação ou da situação.

No caso das noções de morte e violência, os interditos perpassam redes abrangentes, sociais ou mentais, em que as temáticas no cotidiano tendem a ser negadas ou vinculadas a um tipo de apreensão passível de visualização. As diversas formas de apropriação parecem se fazer a partir da intencionalidade do ato em função da pessoa e, desse modo, aparecem como uma forma de apropriação não social do produto da ação.

A morte, como conceito e expressão, encontra-se interdita na sociedade ocidental contemporânea. O modo de vida atual impede a vivência da morte sob um discurso de juventude eterna e dominação da natureza; a morte acontece e é entendida como uma forma de fracasso tecnológico. Como não pode ainda ser evitada, é aventada como a morte do outro e, como tal, as formas rituais e as expressões de dor são minimizadas e tratadas de modo higiênico.

Estudos sobre o Brasil urbano do final do século passado constatou as formas interditas no trato da morte e do luto, o desconforto advindo, a diminuição e o esfacelamento das relações sociais, ampliando a esfera da solidão do homem comum (Koury, 2001, 2003).

A objetividade do social funciona como uma espécie de regramento das subjetividades, enquadrando-as dentro de significados psicológicos que podem interferir no comportamento social em geral, se não forem embargadas ou, pelo menos, 
acionados controles morais para sua contenção. Além disso, a manipulação pode ser feita por meio de subjetividades intencionais, dentro de um rígido controle disciplinar imposto socialmente pelo outro da relação. Controle disciplinar ativado pelas noções de vergonha ou culpa, sempre pessoais, mas também referentes às inter-relações possíveis, vinculadas direta ou indiretamente com o meio social mais geral (Elias, 1990, 1993).

Pensar o objeto fotográfico, em sentido amplo, refere-se à apropriação. A apropriação do real e sua transformação em realidade captada e revelada, capaz de reproduzir um espaço que foi visto e capturado por uma lente e transferido na sua imortalidade de objeto revelado para todo e qualquer olhar que a ele se atenha.

Artefato de objetificação do real, a fotografia submete a realidade ao olhar mecânico da máquina e, através dele, parece disciplinar o conjunto de fatos capaz de organizar um discurso sobre o mundo e os homens, ou dos homens e seus mundos e suas relações com a natureza e o sobrenatural. A fotografia aparece, assim, como uma forma singular de apreensão do real, e seu uso tem um significado variado segundo as formas de assimilação ou os discursos produzidos a partir dos elementos conotados que a constituem.

Uma mesma fotografia representa uma infinidade de formas de apreensão e apropriação segundo os usos a que se encontra submetida. Os interditos, quando agem, funcionam sempre em relação aos outros, espaço onde se objetifica o social, embora internamente, na subjetividade da pessoa, possam ser apropriados de forma diferente. O sentimento de culpa pela posse ou guarda de uma fotografia, por exemplo, permite ressignificá-lo em uma simbologia que acomoda essa culpa da posse, transformando-a em uma emoção qualquer, sentimental, em relação ao objeto de que se fez guardiã ou proprietária.

Os dramas internos acomodados e o objeto, sendo de significação apenas pessoal, sem o controle e o aparecimento público, é possível administrá-lo e conviver com ele na sociedade. Descoberto, porém, ou entreaberta a possibilidade de posse sobre objetos interditos ou de suspeição social, a pessoa se sentirá constrangida, terá receio de passar vergonha em público e, em último caso, ser levada a um tratamento especializado por conta de sua fixação em objetos não aprovados socialmente.

Este parece ser o caso da Foto 1. Esta foto é um dos resultados da democratização da fotografia, que popularizou o ato de retratar e inseriu, de modo mais arraigado, o fotografar no âmbito do privado. Ela foi colhida por mim durante um trabalho de campo sobre luto e sociedade ${ }^{2}$ em uma cidade do interior de Minas Gerais. Retrata um homem pendurado pelo pescoço em um dos caibros da residência. Foi tirada por um familiar, a pedido da esposa da vítima, após ter sido encontrado e antes de a polícia chegar e se apropriar do corpo para perícia técnica. O retrato é guardado com carinho como a única lembrança deste ente pela esposa. Faz parte do que se convencionou chamar álbum de família: instrumento privado em que se depositam as lembranças iconográficas

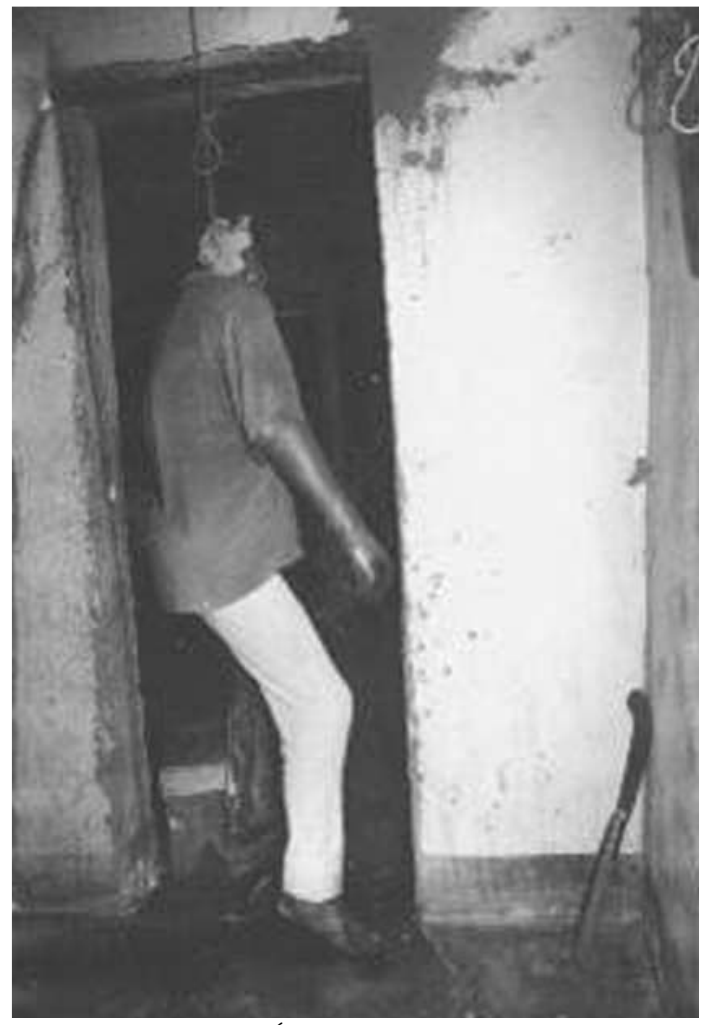

Foto 1 - Anômima - Álbum de família. 
familiares, de amigos próximos e pessoas importantes que, de forma direta ou indireta, estiveram presentes na vida e na organização familiar.

Essa fotografia não possui qualquer expressão pública. Trata-se de uma apropriação privada em um instante familiar. Um instantâneo que retrata o último momento de um ente querido. Os elementos de interditos aparecem quando, a pedido da proprietária, a situação pôde ser revelada, mas não puderam ser discriminados o nome do retratado, da proprietária e da família, nem o local exato onde aconteceu o ato, suicida e fotográfico.

Tratar-se de uma foto de um homem enforcado ainda preso à corda que o matou parece ser um detalhe na administração sentimental dos familiares que a possuem e a utilizam como objeto de memória sentimental do morto. ${ }^{3} \mathrm{~A}$ foto, contudo, é mantida sob um misto de segredo e receio.

É considerada na comunidade, entre vizinhos e inclusive familiares, uma espécie de doença mórbida - "esta mulher é maluca" -, ou por meio de expressões de nojo e distanciamento, como se a foto, e através dela, a família que a possui, pudesse contaminar os demais pela afronta que representa: a idéia de um suicídio acontecido de fato, naquela residência.

A idéia de morte adjetivada pelo suicídio traduz um receio sobre as conseqüências que poderá trazer à comunidade. Evitar a fotografia e, por conta disso, evitar relações mais estreitas com a família que a guarda de maneira sentimental, parece ser o mais prudente a fazer.

A fotografia mortuária no século XIX e nas primeiras décadas do XX foi um instrumento de lembrança de importância especial para os álbuns de família. Por intermédio das fotos repassava-se para as gerações seguintes os que um dia fizeram parte da família, assim como se administrava o estatuto social da família em fotos de velórios, onde o corpo morto era rodeado por familiares e autoridades, amigos, pessoas comuns, agregados entre tantos outros. Estudiosos como Bourdieu (1967), Jay Ruby (1995, 2001), Koury (2001a), entre outros, estudaram o fenômeno na Europa, nos Estados Unidos e no Brasil, respectivamente.
No Brasil, a fotografia mortuária foi largamente utilizada nas classes alta e média até o final de 1950, quando fotógrafos retratavam mortos para álbuns privados. O desuso desse tipo trabalho deuse no final dos anos de 1950, embora ainda seja freqüente o envio dessas fotos com dedicatórias, são elas guardadas com carinho e utilizadas como recordação por grande parte da população urbana de classe média, como mostra a Foto 2, de uma família paraibana, tirada em 1961. Esta fotografia foime cedida durante trabalho de campo sobre luto e sociedade no Brasil por uma das irmãs da mulher retratada, na cidade de João Pessoa, Paraíba. Faz parte do álbum de família desta informante.

A contradição entre a diminuição significativa desse costume e o freqüente uso ou guarda de fotografias mortuárias entre os brasileiros contemporâneos é apenas aparente. De um lado, essas fotos, nos últimos quarenta anos tem sido cada vez mais tiradas por fotógrafos amadores, quase sempre membros da família do morto, o que retira para a instância do privado um ato até então público. De outro lado, porém, a saída para o âmbito privado

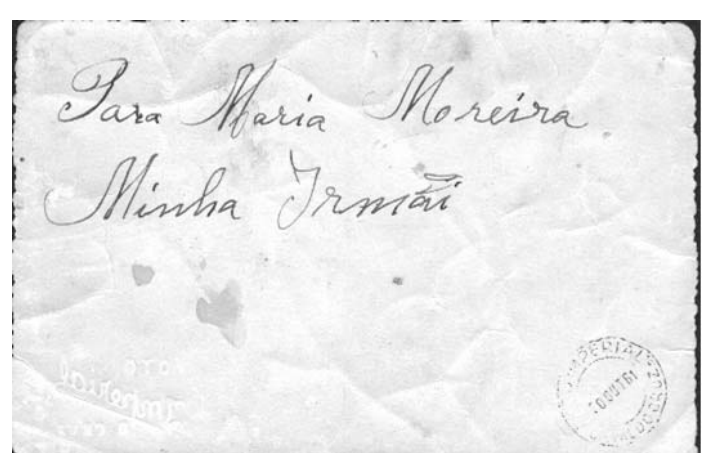

Foto 2a - Anônima - Álbum de família.

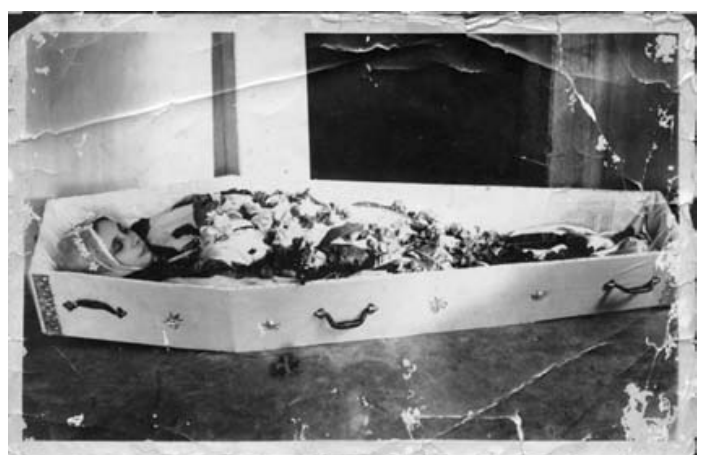

Foto 2 - Anônima - Álbum de família 
ampliou, nas relações públicas, uma espécie de interdito sobre esse tipo de retrato.

A modernidade brasileira veio acompanhada de um discurso de higienização das relações sociais e do trato da morte. Levou a um estranhamento das formas de expressão de sentimentos vigentes e a um arrefecimento dos rituais. As relações e os discursos proferidos a propósito do processo da morte e das formas de agir quando as pessoas são atingidas direta ou indiretamente tornaram-se ambíguos e ambivalentes.

A fotografia mortuária tornou-se, assim, interdita. Uma espécie de "proibição branca" faz com que seu uso hoje seja dissimulado pelos que o praticam e criticado de uma maneira geral. Quando essas pessoas são questionadas se fotografam seus mortos, a primeira expressão é de receio ou indignação, para depois, ao ganhar confiança, confessam que possuem ou tiram fotos mortuárias de entes queridos.

A vergonha da posse é uma expressão moderna do interdito sobre a propriedade de fotografias mortuárias, o que faz a apropriação ser constrangida e a relação pública de expressão social ambígua e ambivalente. O medo de ser tratado de louco, de estranho e motivo de gracejos ou preconceito, circunscreve o retrato dos mortos ou sua guarda e reverência em uma espécie de sombra, com pouca ou nenhuma visibilidade social. O mesmo acontece com as expressões de sentimento e rigor ritual no trato com a morte e com os mortos.

A comparação entre o estado mórbido da Foto 1, que retrata um suicida, e o da Foto 2, que retrata uma jovem morta em seu caixão, dedicada para a irmã como lembrança dos últimos momentos, é bastante fecunda e se faz necessária. A primeira não expressa apenas o sentido de recordação, mas relata a forma com que o retratado foi morto e o tipo de morte, o que torna essa foto e quem a possui como lembrança íntima algo no mínimo bizarro, aos olhos dos outros.

A segunda também incomoda, mas é possível de ser administrada socialmente como um costume antigo, já que muitos possuem retratos desse tipo ou conhecem quem os conserva. Já a Foto 1 apregoa repugnância, não só pelo interdito da morte, mas pela morte adjetivada no ato suicida.
Ambas possuem para o olhar exterior uma conotação não moderna de reviver a morte e os mortos. A primeira, porém, intimida os demais pela "presentificação" de um ato voluntário contra a vida. Na cultura cristã, o suicídio é encarado como um desafio a Deus e está sujeito, portanto, a uma denegação simbólica que prende o suicida senão no inferno, a vagar por entre mundos, sem nunca obter a salvação e a misericórdia. Ação essa que compromete não apenas quem o praticou, mas toda família.

Até que ponto uma etiqueta social tem necessidade de elementos considerados sujos e poluidores para a formulação de uma padronização do comportamento individual e coletivo? A insistência da família em guardar a fotografia que eterniza o ente querido preso a uma corda como lembrança íntima reforça a estranheza sobre ela, concretizando o perigo da sujeira, atualizada e fixada na fotografia, em contaminar a quem dela se aproxime ou toque (Douglas, 1976). O perigo é sentido e deve ser evitado a qualquer custo, o que leva as pessoas a se esquivarem das relações com a proprietária e sua família. As fotos servem de enredo a conversas sobre a etiqueta da morte e do morrer, como um elemento positivo de evitação das regras que erigem o comportamento do enlutado em relação aos mortos e aos membros da família e da comunidade e vice-versa.

A terceira fotografia utilizada neste ensaio retrata um homem jovem agonizante, vítima da Aids, cercado pelo carinho e sofrimento dos familiares. Esta fotografia de Therese Frare, de 1992, teve como destino-alvo uma campanha publicitária da Benetton. Ao lado esquerdo, embaixo, ob-

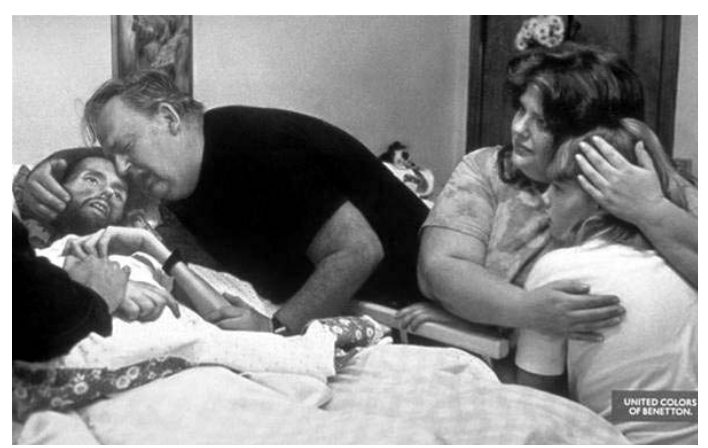

Foto 3 - Therese Frare. Aids. Propaganda da Benetton. 
serva-se uma tarjeta verde que identifica a marca da campanha (Foto 3).

Como as outras fotos, esta retrata um drama familiar de cunho privado, no caso, o acompanhamento da agonia de um ser humano por sua família. Fotografia que poderia ser destinada ao álbum de família, como recordação.

Ela reedita, assim, a simbologia da fotografia mortuária. ${ }^{4}$ Junto à agonia da morte retratada no rosto do doente, pode-se enxergar também um sentimento de satisfação, por estar, talvez, acompanhado pela solidariedade dos que o amam e a que ama. A emoção dos familiares revela a solidariedade e o conforto que querem transmitir, ao mesmo tempo que se expressa, claramente, a inconseqüência da morte.

A foto parece retratar um momento privado que se quer reter na memória familiar e que pretende conservar, para as novas gerações, a singeleza e a importância da família como estrutura social. Das três fotos, esta talvez seja a mais crédula e a que melhor expresse a fotografia mortuária de cunho privado e que destaca o significado da família como um bem universal a ser conservado. Uma fotografia que, embora olhada com certo viés de passado, de tradição, poderia ser suportada pelos olhos da cultura ocidental individualista mais chegada a memoriais.

Contudo, trata-se de uma cena real feita para ilustrar a publicidade de uma grife internacional de roupas. Sua veiculação foi proibida em vários países pelo discurso moral provocado, sendo bastante comentada na mídia internacional da época. Uma semana após seu lançamento foi interditada nas cidades italianas e a seguir, país a país, proibiuse sua exibição. Três ordens de consideração podem explicar a proibição. A primeira remete ao moribundo: por se tratar de um doente terminal de Aids, criou-se uma espécie de estigma, já que a própria enfermidade é vista com preconceito, chamada de "praga mundial" e, sobretudo, urbana, identificada no final de 1970, e que atingiu o auge nos primeiros cinco anos da década de 1990 - a fotografia data de 1992. A segunda indica a indignação internacional orientada pelas igrejas e por instâncias jurídico-políticas por ela ter sido produzida para uma campanha publicitária e, como tal, paga aos familiares e ao doente. O elo sacrossanto que poderia haver na fotografia para uso privado foi quebrado e o debate sobre a frágil estruturação da família moderna, ampliado. A terceira sintetiza as anteriores, indicando a origem e o papel que a fotografia deveria desempenhar e, em contrapartida, o papel que de fato desempenhou: vender um produto específico, no caso, roupas da grife Benetton.

A discussão moral resultou numa bandeira ética contra o uso de determinadas temáticas para propaganda. Alastrou-se pela sociedade civil em manifestos contra a forma e o uso de temas prejudiciais a segmentos determinados da população, ou que ajudariam a ampliar os preconceitos. Assim, grupos organizados pronunciaram-se contra a $\mathrm{Be}$ netton e sua linha de propaganda.

Vale lembrar que a Benetton envolveu-se em diversas disputas jurídico-políticas e acarretou vários protestos com outras fotografias temáticas. Em 1991, por exemplo, a fotografia "o anjo e o demônio", de Oliviero Toscani, retrata duas crianças se abraçando, uma branca e uma negra. Ambas olham direto para a câmera. O "bem e o mal" abraçados parodiam as representações cristãs sobre a imagem do anjo e do demônio. Uma brincadeira contra o preconceito, talvez! Entretanto, não foi absolutamente entendido dessa forma. No Brasil, diversas organizações protestaram contra o preconceito advindo da imagem e conseguiram diminuir o tempo de sua divulgação.

Em 1995, duas fotografias conjuntas, também de Oliviero Toscani, criavam a idéia temática da propaganda. Um casal de homossexuais masculino e um feminino, este último com uma criança, simbolizavam o tema liberation. O cartaz também causou polêmica e protesto em vários países.

No ano anterior, uma fotografia intitulada "Soldado Bósnio" retratava uma calça militar e uma camisa de algodão encharcadas de sangue e com perfuração de balas. Em 1998, a série "Inimigos" unia judeus e árabes, servos e bósnios, e outros inimigos étnicos abraçados. A mais comentada, com protesto de várias organizações judias, foi a fotografia de Oliviero Toscani, de uma moça judia beijando um rapaz palestino, no front.

A Benetton, polêmica armada, ganhava os jor- 
nais e se fazia conhecida e discutida mundialmente. A apropriação de imagens traumáticas de conteúdo moral ou de linguagem ambígua pela propaganda parece atingir o público pela utilização da ambivalência inerente aos estatutos do individualismo e da individualização ocidental contemporânea. De um lado, tudo é possível, do outro, nem tudo, antes pelo contrário.

Ao jogar a ambigüidade como temática, esse tipo de campanha publicitária apontou a aleivosia do cosmopolitismo ocidental e realçou o preconceito, a solidão e o não saber agir dos sujeitos na cena social. O debate sobre até que ponto a liberdade de ações individuais são ativas e quais os limiares de admoestação do novo na sociedade contemporânea expandiu-se. O que é ético, o que é preconceito e o que é razão moral, enfim?

Essas questões foram também suscitadas quando da discussão em torno de uma fotografia que retratava um abutre pousando, pacientemente, próximo a uma menina subnutrida. Sem condições de seguir, a criança pára, as pernas ficam o chão sem forças, ela cambaleia e senta sobre os joelhos; pela tontura do sol, da fome e da sede, sua a cabeça queda e se entrega ao abatimento. O abutre, ave de rapina acostumada a essas cenas, espera pacientemente o desfalecimento da vítima para, talvez, dar o golpe mortal e alimentar-se dos restos (Foto 4).

Esta é uma descrição linear de uma fotografia tirada em 1993 por um fotógrafo sul-africano. A cena passa-se na África, perto de um campo de re-

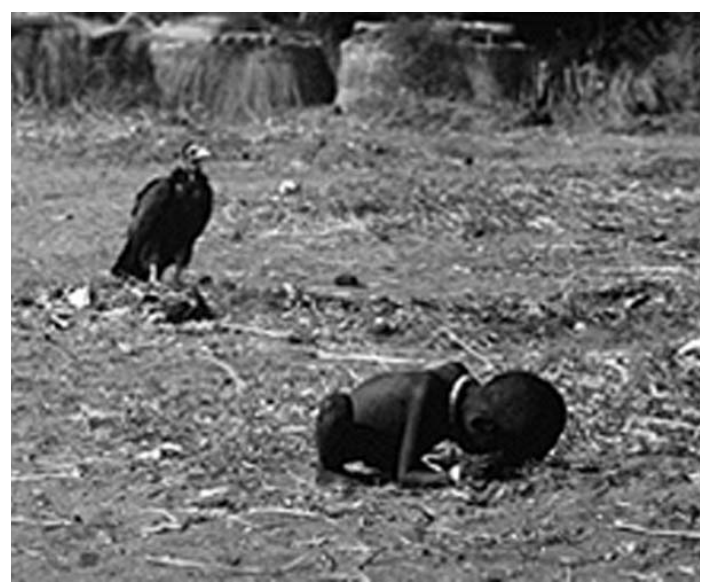

Foto 4 - Kevin Carter - O abutre e a menina sudanesa. fugiados no Sudão. O fotógrafo estava no local para cobrir o impacto causado por mais um conflito entre etnias em disputa pelo controle estatal, na modernidade africana. Como o abutre, pacientemente, ele se posicionou e esperou, acompanhando a trajetória de dor desta pequena tragédia humana, os rodopios e o ganhar segurança da ave diante do alvo.

Com esta foto, Kevin Carter ganhou o prêmio Pulitzer de fotojornalismo em 1994 e, algum tempo depois, suicidou-se aos 33 anos de idade.

Ele até então era pouco conhecido no mundo do fotojornalismo. O obituário de autoria de Scott Macleod, publicado na revista Time, de 12 de setembro de 1994, informa que Carter ganhou notoriedade internacional por meio desta fotografia, e que sua repercussão se deu em um dos acasos da vida cotidiana. Fotógrafo free-lance conhecido apenas na África do Sul, segundo artigo de Judith Matloff no Columbia Journalism Review, de novembro/dezembro de 1994, após fotografar as vítimas do Sudão, retornou a Johannesburg. Por coincidência, o New York Times procurava fotografias sobre o país e comprou algumas de Carter. A fotografia da menina sudanesa foi publicada na edição de 26 de março de 1993, causando grande impacto na opinião pública norte-americana e mundial.

A notabilidade da fotografia se deveu por tocar sentimental e politicamente os olhares observadores mais diversos - do homem comum, até agências de Estado e organismos internacionais governamentais e não governamentais. Primeiro, pela violência emanada, que serviu de suporte para discursos e campanhas de controle e ajuda aos povos que vivem na extrema miséria. Segundo, pelo suicídio do autor, atribuído em bilhete a não mais ter condições de viver depois de presenciado tal ato e participado dele apenas como observador. ${ }^{5}$

Essas questões geraram um intenso debate entre fotojornalistas sobre a ética por trás da captação de imagens. Em outras palavras, a discussão em torno da busca de notoriedade ou da melhor fotografia, sem se importar com quem está sendo retratado. Desde o lado aventureiro do fotojornalismo até as alusões de que os fotógrafos eram caçadores de imagens e a discussão sobre a necessidade de pensar visualmente em campo no processo 
de obtenção de imagens com melhores ângulos ou qualidade técnica sobre o produto retratado, tudo foi tema de discussão. Em depoimento, o fotógrafo James Nachtwey afirma ter ouvido de Carter: "[...] você está fazendo um visual aqui, mas dentro algo está gritando! [...] Mas é tempo de trabalhar. Se lida com o resto depois. Se não puder fazer isso, então saia do jogo".

Passou-se a refletir sobre o processo ético no ato fotográfico em si. O suicídio de Carter, nesse contexto, constituiu-se, usando suas próprias palavras, uma forma de sair do jogo e do não poder mais fazer esse tipo de trabalho. Alguns depoimentos, com o intuito de entender a fatalidade acometida, comentaram a instabilidade emocional do fotógrafo, o consumo de drogas e álcool e o fato de ele buscar notoriedade a qualquer preço. Nessa sentido, esses depoimentos queriam, na verdade, se livrar de um sentimento de culpa mais geral. Culpa presente no ato fotográfico implícito ao trabalho de fotojornalismo; culpa relativa ao consumo de imagens no mundo ocidental contemporâneo e à busca da mídia sem limites de exploração de sentimentos e de ampliação de vendagem das edições, não importando as fronteiras da moral e da ética. A relação entre venda, novidade diária e qualidade da imagem nas agências e nas mídias internacionais, em nome da informação imediata e dos furos de reportagem, impõem aos fotógrafos um modo de agir, no momento mesmo da captura da imagem - um pensar visual -, que separa o trabalho de suas vidas cotidianas.

No meio acadêmico, a análise deteve-se sobre as formas de discurso geradas pela apropriação de imagens traumáticas - dominação e exploração ou/e sensibilização das pessoas. Kleinman e Kleinman (1997, pp. 1-24), a partir da fotografia e do suicídio de Carter, discutem as bases de apropriação do sofrimento social pela política e pela mídia contemporânea na sociedade ocidental. Falam das imagens traumáticas como representações culturais do sofrimento social e suas apropriações para propósitos políticos ou morais; discutem o uso social do sofrimento como um componente da política econômica globalizada contemporânea e da criação de um mercado pul- sante para imagens e discursos sobre o tema. O sofrimento social tornou-se uma mercadoria de grande procura no mercado midiático e de políticas públicas internacionais.

Luc Boltanski (1993) discorre sobre o sofrimento à distância para expressar as formas pelas quais a cultura popular se apropria e é estimulada a se apossar de imagens que traduzem o sofrimento social no mundo e que, nesse contexto, se tornam mercadorias. Alvos de retóricas e de representações discursivas e culturais, essas imagens são como restos pouco densos e distorcidos de uma experiência social que se passou distante dos sujeitos que a vêem. Representações culturais veiculadas por meio de imagens traumáticas, tornadas objetos temáticos, hierarquizados e estigmatizados, geralmente sob a égide protetora e intervencionista de uma moral social dominante e suas instituições.

A mesma discussão ética fomentada pelo impacto causado pela Foto 4 pode também servir de base para as fotos 5 e 6 com uma diferença, contudo. A diferença diz respeito às formas de edição de imagens fotográficas: censura moral, cortes, formas de manipulação e sobre o que deve ser ou não mostrado nas imagens publicadas.

A Foto 5 ilustrou um jornal popular, Folha de Pernambuco, no seu primeiro ano de existência. A fotografia de 1999, do fotógrafo Clemilson Campos, retrata um travesti morto.

A fotografia é banal e retrata uma cena comum: um travesti morto nas ruas, num dos becos da periferia de Recife. A sua composição seria co-

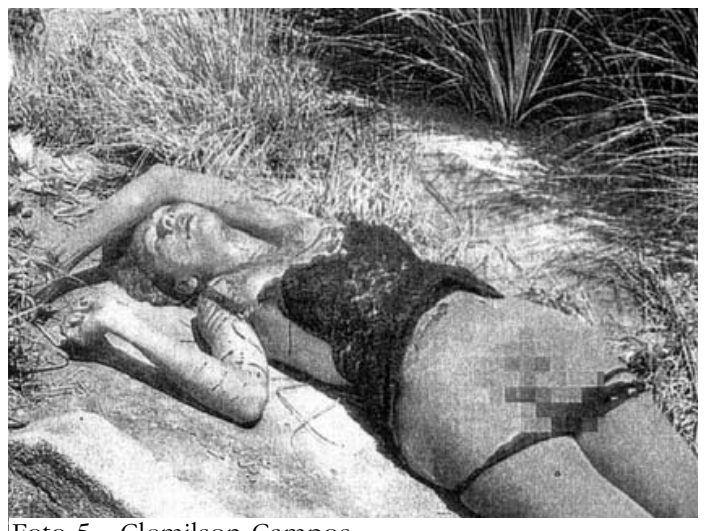

Foto 5 - Clemilson Campos. 
mum à fotografia jornalística de jornais populares tipo de enquadramento, angulação, sangue derramado pela vítima etc. - se não fosse um pequeno detalhe. O travesti morto estava com o pênis ereto.

A editoria resolveu retirar o inconveniente da foto, borrando-o digitalmente, de forma grosseira, conforme depoimento do editor de fotografias do jornal cedido a mim, embora a matéria escrita falasse claramente da ereção da vítima. No mesmo ano, o jornal publicou outra foto, de Hélia Scheppa, com as mesmas características: a manchete chama a atenção - "Idoso achado morto, nu e com pênis levantado". Igualmente, a região peniana se encontra borrada, escondendo e, ao mesmo tempo, mostrando o elemento interdito.

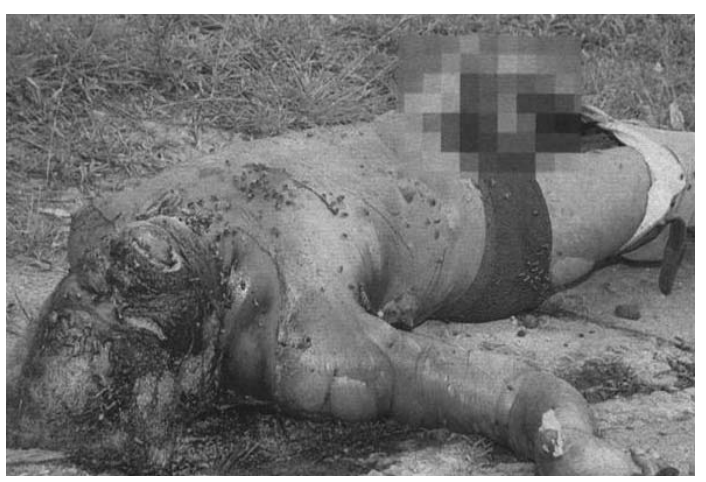

Foto 6 - Hélia Scheppa.

Nessas duas fotografias, está-se falando de imagens traumáticas e de sua expressão na imprensa chamada popular. O sofrimento social tem aí uma intencionalidade direta, como uma espécie de editorial, sobre o significado construído para a violência urbana e seus protagonistas, geralmente populações pobres ou grupos considerados marginais à moral comunitária em vigor.

O papel da imprensa popular na construção das imagens de sofrimento como mercadoria e na sua disseminação como discursos intervencionistas de ação direta ou, ainda, como banalização e estigmatização do sofrimento social é por demais debatido, seja como espetáculo da experiência específica de um segmento da população - pessoas comuns, moradores das periferias das cidades, trabalhadores ou desempregados; pequenos bandidos, estupradores e suas vítimas, homossexuais e travestis; grupos de extermínio organizados, pagos pelo comércio local; grupos de linchamento, que buscam a justiça pelas próprias mãos; a própria polícia, tanto no seu lado corrupto como no de ação e proteção do cidadão -, seja como consumo mórbido. Em um outro trabalho (Koury, 1998, pp. 67-86), ao analisar a questão da indiferença no processo de consumo de imagens traumáticas na imprensa, tendo por base de pesquisa os depoimentos de informantes que foram expostos a um conjunto de fotografias, cujo tema principal era a morte, pude identificar o motivo da banalização e da rotinização desse tipo de imagem.

Embora a morte incomodasse por sua morbidez, não dizia respeito de imediato aos medos, aos receios e às perdas pessoais dos informantes. Sua impessoalidade abria espaço para uma interpretação sobre os horrores e a violência do mundo, sem que afetasse diretamente o mundo pessoal do observador.

A perturbação era mais social, não atingindo diretamente o lado subjetivo da pessoa. Os retratados eram os outros, os homens em abstrato, indivíduos quaisquer, distantes, virtuais, o que tornava possível cada um abstrair, fazendo com que os depoimentos transcorressem em um nível de distanciamento em que as emoções vinham à tona por meio de categorias muito amplas e aparentemente desligadas do cotidiano.

Os elementos indicados servem de pano de fundo para se discutir o significado do corpo na construção imagética de fotografias traumáticas na imprensa popular. O corpo e, especificamente, o corpo morto fotografado fazem parte de um conjunto de símbolos de conotação social. A fotografia na imprensa popular alude o que deve e como deve ser mostrado, e o que deve ser interdito ou censurado. Ela trabalha com os símbolos presentes no imaginário social para expressar uma espécie de ardil visual direcionado à apreensão pelo leitor (Barthes, 1984a, pp. 13-25).

Para Douglas (1976, pp. 141-158), no corpo está expresso todo o poder e o perigo creditado a uma estrutura social. Por meio dessa ligação é que se pode perceber no meio social o limite de exposição, positividade ou negação do corpo, na sua totalidade, em partes ou, ainda, nos excrementos - 


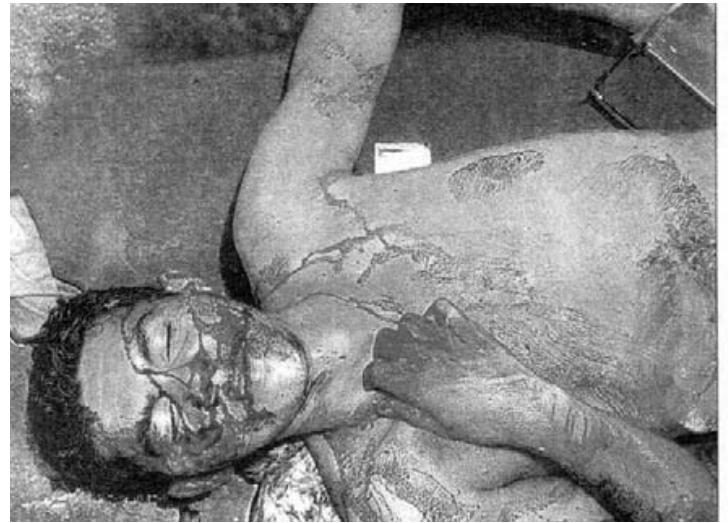

Foto 7 - Hélia Scheppa.

sangue, suor, saliva -, já que nele estão gravadas as imagens da sociabilidade. A fotografia, por intermédio do corpo objetivado, restaura, ao mesmo tempo em que instaura, uma nova leitura ressignificada, o que Turner (1990, p. 87) chama de drama social.

Trata-se de um conjunto de comportamentos ou representações que compõem unidades sociotemporais quase fechadas, sinalizam mecanismos de projeção inconscientes e elaboram um quadro de referência sobre o que é adotado ou o que se deve adotar como critérios para sua apreensão. O simbolismo do corpo, assim, é investido de poder e perigo e age dentro de um plano emotivo, em virtude da experiência imaginária vivida por uma coletividade e introjetada pelos indivíduos que dela fazem parte.

A linguagem do sofrimento nas fotografias de homicídios publicadas nos jornais populares, por exemplo, ao trabalhar com o poder e os perigos do corpo, arremessam um drama social não apenas para as vítimas expostas, mas também para cada indivíduo e toda a coletividade. Drama social que assegura o estatuto social de pertença do retratado e lida com os limiares imaginários da vulnerabilidade e dos perigos a que estão expostos os que com ele se identifiquem ou se horrorizem, no processo de apropriação da imagem retratada.

O corpo morto fotografado, em particular, reveste-se de significados precisos de transgressão em uma ótica de mercado e referencia subliminarmente a condição social do retratado e suas formas de apreensão: perigosa, desviante, violenta.

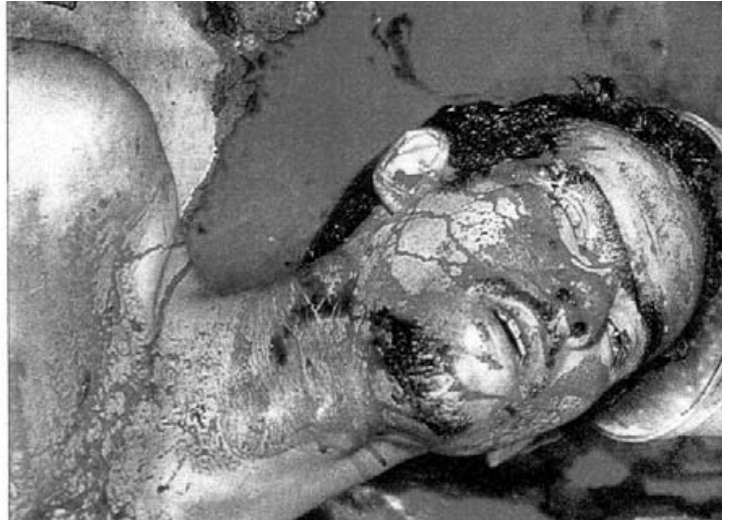

Foto $7 \mathrm{a}$ - Hélia Scheppa.

Ademais, esse tipo de fotografia torna o sofrimento social uma sensação e um objeto de consumo. A fotografia expropria o corpo pela exposição dos elementos que singularizam a morte e a condição social do fotografado, além de mostrar excrementos, líquidos, furos ou pedaços arrancados que projetam o que não deve ser visto, como vísceras, sangue, ossos etc. Ao mesmo tempo, a imagem busca retratar a poluição dos elementos expostos, na sua mistura com a terra e a lama, nos locais ou depósitos de desova, ou na exposição do corpo em degradação a quaisquer passantes.

Duas fotografias publicadas na Folha de Pernambuco de 30 de junho de 1999 (Foto 7) e 12 de maio de 2000 (Foto 8), de Hélia Scheppa e Expedito Lima, respectivamente, são, nesse sentido, reveladoras.. Ambas retratam corpos mortos chacinados, o sangue misturado às impurezas do lugar e, em particular na primeira foto, sujando uma edição do Evangelho.

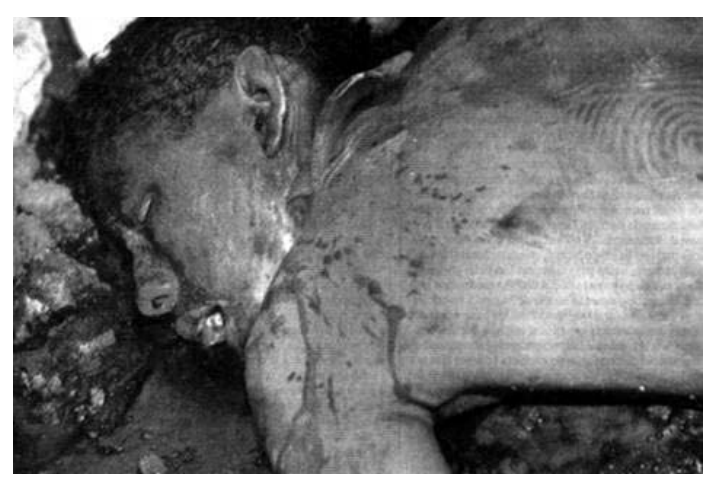

Foto 8 - Expedito Lima. 
Essas fotos vulgarizam o sofrimento, tornando-o uma experiência social banal e distanciada porque enquadrada em uma dramaturgia específica, mas que, concomitantemente, tira todo e qualquer cidadão de seu invólucro protetor, pela poluição representada e os discursos expressos quando impressas.

Como um contraponto, as fotos 5 e 6 trabalham com essas mesmas questões, mas, acima de tudo, singularizam um interdito: o plano que expõe o sexo e sua anomalia na morte fotografada. O sexo masculino ereto, que na sociedade ocidental simboliza potência e virilidade, parece não se enquadrar em um corpo decomposto, vitimado e poluído. Daí a negação e a proibição no plano fotográfico. Proibição visível quando na edição é borrado aquilo que não deve ser mostrado, mas que é destacado pelo rabiscar grosseiro e intencional, pelas manchetes e no decorrer do texto da reportagem.

Contradição aparente entre escrita e fotografia. Aparente porque se, de um lado, o interdito virilidade do membro ereto - se revela ao simples olhar, de outro, ele é introduzido como um sinal de desvio, passível de interpretação risível, como anedota. A relação entre o texto e a foto vulgariza o corpo morto retratado e o reinsere em seu lugar social de exclusão, criando uma imagem parcial e sensacionalista da criminalidade e da pobreza.

\section{Conclusão}

As formas interditas ou os intercâmbios poluidores presentes no registro fotográfico e a reação sobre eles tem muito a ver com a moral. O sofrimento social publicado é repassado como um elemento particular de um fenômeno geral idéia de ordem e segurança -, o qual deve ser enfrentado como ameaça pessoal ou por instâncias competentes. Para Douglas (1976, p. 160), é muito difícil definir as situações morais, pois elas são normalmente obscuras e contraditórias. Servem a diferentes discursos, apropriações e formas subliminares de manipulação e sedução, assim como para uma apreensão abstrata de fenômenos presentes no imaginário social e experienciado por um indivíduo ou grupo social.
É da natureza da regra moral "ser geral e a sua aplicação a um contexto particular deve ser incerta" (Idem, ibidem). As regras de poluição, ao contrário das regras morais, são inequívocas. O objeto fotográfico, trabalhando na fronteira, na abrangência dos códigos morais e na especificidade dos códigos de interditos e de poluição, dentro de uma idéia de experiência abstrata, retrata situações de sofrimento na ambivalência entre abrangência e especificidade e na ambigüidade das regras morais e nas expressões poluidoras e interditas. Torna-se um subproduto da ação legal ou legítima exercida institucionalmente ou, no âmbito privado, uma ameaça concreta ou potencial dos medos que perpassam a sociedade e que modelam seus membros. Pode tornar-se, além disso, uma instância de conformação e conforto sentimental e de memória na esfera da vida privada, ou de ordem e segurança no coletivo que o expressa e de onde se configuram as apropriações discursivas sobre o fato fotográfico em si como objetificação do real.

Para Barrington Moore (1987, p. 622), a legitimidade tende a ser aferida a qualquer princípio de inevitabilidade, seja qual for o sofrimento. Esse princípio nas fotografias traumáticas aparece representado pelas concepções de ordem e segurança que, de forma subliminar, o legitimam. Fazse presente também na banalização e no sensacionalismo dos meios de comunicação nas sociedades ocidentais desde a Segunda Guerra Mundial. A exposição dos corpos na sua banalidade remete o olhar à naturalidade da cena, como se ela fosse algo comum e cotidiano. Reforça a indiferença e, no limite, exalta a morbidez e a inevitabilidade da violência nela contida, ou, ainda, revela o interesse de chocar.

O sofrimento é estigmatizado e negado. É retirado de cena pela amplitude das generalizações que legitimam a morte pública e sua inevitabilidade, transformando-se em experiência abstrata e mercadoria de largo consumo.

A fotografia traumática, ao fornecer uma coleção de objetos parciais, favorece o fetichismo e uma espécie de perversão (Barthes, 1984, p. 51). Em nome de negar a violência incorporada ao sofrimento social, ela legitima a violência em si mes- 
ma, pela descaracterização da imagem nas convenções que reforçam a inevitabilidade do ato registrado nas fotografias.

É possível reconhecer o sofrimento social no enquadramento fotográfico, mas o que se experimenta tem a ver com uma espécie de adestramento; com o meio cultural que formou e do qual necessariamente participa o observador, dando significado às ações, às figuras e às cenas que as fotos revelam. Uma espécie de recalcamento é sombreada: restos perdidos, parcelas inacessíveis ao olhar, que assombram a imagem justamente pelo invisível nela contido, catalogado como morbidez, como inevitável, ou tratado com indiferença.

Como se o sofrimento prenunciado das fotos perdesse seu significado, dando lugar a uma indiferenciação em que tudo se equivale. Espécie de rito de passagem traumática que interroga a linguagem, bloqueia a significação e reforça a noção de inevitabilidade.

Noção que conota um universo regido, em parte ao menos, por forças não suscetíveis à vontade e à ação dos indivíduos, impedindo ou sufocando a indignação moral. Movimentos de auto-ilusão erigidos reforçando a perigosa capacidade humana de acostumar-se às coisas, ou de sufocar os impulsos à violência que das fotos emanam, endurecendo o olhar para enfrentar a tragédia da existência.

\section{Notas}

1 Para uma discussão sobre fotografia e a noção do sagrado, ver, entre outros, Tacca (2002).

2 Sobre os resultados desta pesquisa, ver Koury (2001, 2001a e 2003).

3 Ver, como comparação, o trabalho de Disderi, fotografando corpos mortos e arrumando-os como se ainda estivessem vivos, conforme Dubois (1994). Ver, também, a incorporação sentimental de fotografias de corpos mortos pelos familiares e sua utilização para uma posse simbólica do ente querido que se foi, em Ruby (1995) e Koury (2002).

4 Algumas vezes, observadores enxergaram na encenação proposta nesta foto da Benneton uma simbologia que procurava retratar o Cristo morto na figura do moribundo ou, ainda, a figura de 'Che' Guevara exposta pela mídia, morto pelo exército boliviano. Ver, também, sobre o discurso publicitário e o uso de fotografias traumáticas pela Benneton, o número especial da revista Colors, publicação do grupo Benneton, tendo como editor Oliviero Toscani (1998), e o trabalho de Finco, 1996.

5 Para uma comparação com a forma trágica da fotografia e do suicídio de Carter, ver Sontag (1986, pp. 33-52), que retrata a melancolia do projeto fotográfico norte-americano por meio da trajetória também trágica da fotógrafa Diane Arbus.

\section{BIBLIOGRAFIA}

BARRINGTON MOORE Jr. (1987), Injustiça: as bases sociais da obediência e da revolta. São Paulo, Brasiliense.

BARTHES, Roland. (1984), A câmara clara: nota sobre a fotografia. 4 ed. Rio de Janeiro, Francisco Alves.

(1984a), "A mensagem fotográfica”, in O óbvio e o obtuso, Lisboa, Edições 70, pp. 13-25.

BENNETON GROUP. (1998), Colors, n. 24, "Morte - Instruzione per l'uso. Death - a user's manual".

BOLTANSKI, Luc. (1993), La souffrance a distance. Paris, Metailie.

BOURDIEU, Pierre (org.). (1967), Un art moyen: essai sur les usages sociaux de la photographie. 3 ed. Paris, Minuit.

DOUGlas, Mary. (1976), Pureza e perigo. São Paulo, Perspectiva.

DUBOIS, Phillippe. (1994), "O corpo e seus fantasmas", in O ato fotográfico e outros ensaios, Campinas, Papirus.

ELIADE, Mircea. (1992), O sagrado e o profano. São Paulo, Martins Fontes.

ELIAS, Norbert. (1990 e 1993), O processo civilizador. Rio de Janeiro, Jorge Zahar, 2 vols.

FINCO, Henrique. (1996), O paradoxo Benneton: um estudo antropológico de uma ocorrência de discurso publicitário. Florianópolis, Editora da UFSC. 
KLEINMAN, Arthur \& KLEINMAN, Joan. (1997), "The appeal of experience; the dismay of images: cultural appropriations of suffering in our times", in Arthur Kleinman, Veena Das e Margaret Look (eds.), Social suffering, Berkeley, University of California Press, pp. 1-24.

KOURY, Mauro Guilherme Pinheiro. (1998), "Fotografia e a questão da indiferença", in (org.), Imagens \& ciências sociais, João Pessoa, Editora Universitária, pp. 67-86.

. (2001), Ser discreto: um estudo sobre o Brasil urbano atual sob a ótica do luto. Relatório de Pesquisa, João Pessoa, Grem/DCS/UFPB.

(2001a), "Você fotografa os seus mortos?", in (org.), Imagem e memória: ensaios em antropologia visual, Rio de Janeiro, Garamond, pp. 51-94.

(2002), Uma fotografia desbotada: atitudes e rituais de luto e o objeto fotográfico. João Pessoa, Manufatura/Grem.

(2003), Sociologia da emoção: o Brasil urbano sob a ótica do luto. Petrópolis, Vozes.

RUBY, Jay. (1995), Secure the shadow: death and photography in America. Cambridge, Massachusetts, MIT Press.

(2001). "Retratando os mortos", in M.

G. P. Koury (org.), Imagem e memória: ensaios em antropologia visual, Rio de Janeiro, Garamond, pp. 95-111.

SONTAG, Susan. (1986), "A América vista através de fotografias, sombriamente", in Ensaios sobre a fotografia. Lisboa, Publicações dom Quixote, pp. 33 a 52.

TACCA, Fernando Cury de. (2002), "O sagrado em imagens", in Anna Balog et al. (orgs.) Mídia, cultura, comunicação, São Paulo, Arte \& Ciência.

TURNER, Victor. (1990), Le phénomène rituel: structure et contre-structure. Paris, PUF. 


\section{FOTOGRAFIA E INTERDITO}

Mauro Guilherme Pinheiro Koury

\section{Palavras-chave}

Fotografia; Interdito; Sofrimento social; Código moral;

Representações culturais.

Este ensaio trabalha com a problemática do interdito e sua relação com o objeto fotográfico. Discute as imagens traumáticas como representações culturais do sofrimento social, suas apropriações para propósitos políticos ou morais, e o uso social do sofrimento como um componente da política econômica globalizada contemporânea. Analisa, ainda, a criação de um mercado pulsante para imagens e discursos sobre o tema.

\section{PHOTOGRAPHY AND INTERDICT}

Mauro Guilherme Pinheiro Koury

\section{Key words}

Photography; Interdict; Social suffering; Moral code; Cultural representations.

This paper works with the problem of the interdict and its relationship with the photographic object. It discusses traumatic images as cultural representations of social suffering, its appropriations for either moral or political purposes, and the social use of suffering as a component of the contemporary globalized economic politics. It also analyses the creation of a vigorous market for both images and speeches on the theme.

\section{PHOTOGRAPHIE ET INTERDIT}

Mauro Guilherme Pinheiro Koury

\section{Mot-Clés}

Photographie; Interdiction; Souffrance Sociale; Code moral; Représentations Culturelles.

Cet article aborde la problématique de l'interdit et son rapport avec l'objet photographique. L'auteur propose une discussion à propos des images traumatisantes comme constituant des représentations culturelles de la souffrance sociale, de son appropriation pour des propos politiques ou moraux et de l'usage social de la souffrance comme une composante de la politique économique globalisée contemporaine. Il analyse également la création d'un marché énergique pour les images et les discours sur ce thème. 